\title{
On Function of Basic Principles of Criminal Proceedings
}

\author{
Jinshan $\operatorname{Han}^{1, \mathrm{a}}$ \\ ${ }^{1}$ Base of Training, Army Logistics University of PLA, Chongqing 401331, China \\ ${ }^{a}$ Email:286786800@qq.com
}

\begin{abstract}
With the functions as the legislative rule, as the code of conduct and of empowering the judges with active justice, the function of the basic principles of the criminal proceedings refers to the inherent performance or functions of the basic principles of the criminal proceedings as a special legal norm itself. Its function as legislative rule shows that it is the legislators' law of conduct and therefore constitutes a restriction on the legislative power. Its function as the code of conduct indicates that it must be followed by the specialized state organs and the participants in the criminal proceedings. Its function of empowering the judges with the active justice shows that the basic principles of the criminal proceedings can explain the basis of the criminal procedure law and supplement its loopholes.
\end{abstract}

\section{Keywords: Function, Basic principles of criminal proceedings, Criminal action}

\section{INTRODUCTION}

As the most important and core of the criminal procedure activities embodying the purpose and characteristics of modern criminal proceedings, the basic principle of the criminal proceedings refers to the legal truth and the code of conduct which have universal guiding significance to the legislation and judicial practice of the criminal proceedings. Playing an important role in the theory system of the criminal procedure law, the basic principle of the criminal proceedings is not only an important part of the system, but also a comprehensive and comprehensive theoretical summary of the nature, characteristics and laws of the criminal proceedings. [1] It is not only the important embodiment of the legislative thought of the criminal proceedings, but also the guiding ideology of the whole operation mechanism of the criminal proceedings, which plays a normative and binding role in the criminal procedure behavior. The understanding and research on this issue is not only directly related to the construction of democratic, civilized and scientific criminal procedure, but also to the development of the criminal procedure legislation and judicature.

The functions of the basic principles of the criminal proceedings refer to the inherent performance or functions of the basic principle of the criminal proceedings as a special legal norm itself. That is to say, whether or not the criminal procedure law directly and practically affects the society, the performance or functions of the basic principles of the criminal proceedings is always inherent because these functions are actually based on certain potential capabilities determined by the attributes of the law itself, its internal elements and structure. And this paper holds the idea that the basic principles of the criminal proceedings have the functions as the legislative rule, as the code of conduct and of empowering the judges with active justice.

\subsection{Related Work}

The process of understanding and development in the research of the functions of the basic principles of the criminal proceedings in the legal circles in China can be divided into two periods.

\subsubsection{Previous research}

In the early research, when discussing the principles of criminal procedure law, scholars pointed out that it is of great significance to study the principles of the criminal procedure law seriously to correctly understand and implement the spiritual essence of criminal procedure law, and to improve the quality of handling cases. [2] Obviously, this understanding of the function of the principles of the criminal procedure law is simple and superficial. 
Since then, with the in-depth study of the principles of the criminal procedure law and the reference to the research results of other legal disciplines, the understanding of the principles of the criminal procedure law has also begun to profound and comprehensive. Some scholars have proposed that the function of the criminal trial principles includes the following five aspects: the function of carrying, balancing and coordinating the value of various procedures, the function of determining and influencing the basic structure of the criminal trial process, the function of guiding the criminal procedure legislative activities in the legislative branch as a basic legal principle, the function of adjusting the litigation actions of the parties to the criminal procedure as a procedural norm, and the function of guiding the active judicial activities of the judiciary. [3] This induction is quite comprehensive. However, it would not be appropriate to host, balance and coordinate values, as well as the function of determining and influencing the basic structure of criminal trial proceedings along with the other three functions. Because the first two function are not independent and need to be implemented through the last three.

\subsubsection{Current research}

At present, the research on the basic principles of the criminal proceedings is still based on the study of the principles of the criminal procedure law. Its representative view is that the function of the principles of the criminal procedure law is embodied in the following three aspects: the function to guide the criminal procedure legislation, the function to guide the conduct of the criminal proceedings and the function of guaranteeing the realization of the criminal procedure task. [4]This point of view correctly points out the guiding significance of the principles of the criminal procedure law to legislation and judicial activities. But the above three functions cannot be juxtaposed. Because the function of guaranteeing the realization of the criminal procedure task is actually the fundamental one, while guiding the legislation and judicial practice are its concrete functions. Therefore, the two cannot be at the same structural level and it is inappropriate to juxtapose them.

\subsection{My Contribution}

Based on the above research, this paper holds the idea that the basic principles of the criminal proceedings have the functions as the legislative rule, as the code of conduct and of empowering the judges with active justice.

\subsection{Paper Structure}

The rest of the paper is organized as follows. Section 2 to 4 discusses the basic principles of the criminal proceedings have the functions as the legislative rule, as the code of conduct and empowering the judges with active justice. Finally, Section 5 concludes the paper and presents the directions for future research.

\section{FUNCTION AS LEGISLATIVE RULE}

The function of the legislative rule of the basic principles of the criminal proceedings means that as a fundamental rule, the basic principles of the criminal proceedings constitute the principle or basis of other legal norms. The formulation of other legal norms of the criminal proceedings must be based on and logically take its basic principles as the starting point. When formulating the rules of criminal proceedings, the legislators must follow the content and spirit of its basic principles. In this sense, the basic principles of the criminal proceedings are the legislators' code of conduct, which prevents their arbitrary intentions and thus constitutes a restriction on the legislative power. When formulating the criminal procedure law, the legislators will first determine the basic principles that can reflect these values and the requirements of the purpose according to the value objectives and the purpose of the proceedings they seek.

The basic principles of the criminal proceedings carries the most fundamental requirement of the criminal proceedings, and expresses the legislators' value and purpose pursuit to formulate the criminal procedure law. Therefore, it can play the benchmark functions of legislation, regulate the specific principles, systems and norms of the criminal proceedings in line with its purpose and do not deviate from its value orientation. So the whole norms of the criminal proceedings are coordinated.

The connotation of the basic principles of the criminal proceedings contained the value orientation and the legislators' pursuit of purpose must also be expressed and realized through the specific norms. Therefore, when formulating the specific norms of the criminal procedure law, we must first formulate the basic principles and take them as the starting point and norms contrary to the spirit of the basic principles are invalid. So the basic principles of the criminal proceedinds are the starting point and destination of formulating the specific norms of the criminal procedure law. Just like Rocos Pound, a scholar from the United States once said: "A principle is an authoritative starting point for legal reasoning. Legal principles are a new product of the organization of judicial experience by the legal workers. They differentiated the various cases and set a principle behind the distinction, comparing the long-standing experience of judgement in a given field 
to facilitate reasoning, either attributing some cases to a general point of departure and others to another point of departure, or identifying a more inclusive point of departure applicable to the entire field. " [5]

\section{FUNCTION AS CODE OF CONDUCT}

As the constituent element of the legal norm system of the criminal procedure law, the basic principles of the criminal proceedings are legally binding on all parties involved in criminal actions. This characteristic makes the basic principles of the criminal proceedings not only play the function of the legislative norms, but also become the code of conduct which must be followed by the specialized organs of the State and the participants in the proceedings. So, the basic principles of the criminal proceedings, together with other procedural rules, adjust the litigation behavior of the specialized organs of the State and the participants in the criminal actions.

The purpose of the laws is to regulate society and people's behavior, so the law has become the general norm of civic behavior. Whether based on the morality or coercion, law-abiding is the basic obligation of the citizens. As a part of a national legal system of the criminal procedure, the basic principles of the criminal proceedings should also be the basic principles that citizens must abide by in conducting the criminal procedure activities as the participants in the proceedings. If the participants in the proceedings violate the basic principles, they will bear adverse legal consequences. For example, in a private prosecution case, a private prosecutor who has entered into force against the principle of non- bis in idem will re-indict the case to the court, which will not be accepted.

On the other hand, the state institutions in modern countries governed by the rule of law must also be subject to the control of the law while acquiring power from the law. Therefore, as law enforcers, the state institutions should also become the subject of lawabiding acceptance of the law. In the criminal procedure activities, the specialized organs of the state that undertake the functions of investigation, prosecution and trial- the investigation organs, the prosecutorial organs and the courts, on the one hand, as law enforcers, should carry out and implement the basic principles of the criminal proceedings. And on the other hand, they should abide by the basic principles of the criminal proceedings as law-abiding subjects. Violating the basic principles of the criminal proceedings, the specialized organs of the State should also be considered to be illegal and will therefore bear adverse legal consequences. For example, if the investigative authorities conduct a search without permission, the evidence obtained through the search will not be accepted by the court.
So, as far as the specialized organs of the State are concerned, the basic principles of the criminal proceedings actually has the dual functions of lawabiding and law-enforcement norms. The function of the law enforcement criterion of the basic principles of the criminal proceedings is embodied in providing the legal basis for the law enforcement of the investigation organs, the prosecutorial organs and the courts in a positive way; in the negative aspect, it is reflected in the limitation of the discretion of the organs mentioned above. In the course of the application of the criminal procedure law, the exercise of discretion is also involved. For example, as far as the application of coercive measures is concerned, there is a question of how to grasp appropriateness and moderation. Such as the specific amount of bail received, the duration of detention and so on, the law does not provide a clear standard and how to operate it depends on the discretion of the law enforcers. If not restricted, this discretion will also result in the abuse of power, thereby threatens the personal and property rights of the citizens. Therefore, the discretion like this must be reasonably limited. It requires the basic principles of the criminal proceedings to play a role.

\section{FUNCTION OF EMPOWERING JUDGES WITH ACTIVE JUSTICE}

Historically being seen as a legal machine, the judges can only passively accept facts and laws and pass judgments. The formation of this concept is based on the fear of human weakness and the distrust of the judges, and trying to achieve the justice of the law by eliminating the initiative of the judges. However, in the complicated reality, obliterating the subjective initiative of the judge is precisely the damage to the justice of the law. Especially in today's complex social environment, the enactment of law has been difficult to meet the needs of the social development with the new cases emerging and new situations happening. It is an indisputable fact that the judges are required to give full play to their actions to balance and coordinate the social relations. However, as was once feared, the judges' excessive and unlimited power would inevitably lead to arbitrariness. Therefore, while giving the judges the discretion necessary to move the judiciary, it is essential to control such power. [6] The basic principles of the criminal proceedings provide the basis for the judges' discretion and give them the ability to carry out judicial activities creatively.

In criminal proceedings, the judges' creative judicial activities mainly include two levels: the physical content and the procedural one. To the physical content, on the one hand, according to the spirit of the basic principles of the criminal proceedings, the judges makes a purposeful interpretation of the legal norms through active justice, and on this basis, the legal norms are 
correctly and reasonably applied to the specific cases, so as to coordinate the contradiction between the general justice of the law and the individual justice of the specific cases. On the other hand, when there is no clear stipulation in the law, the judges can "create the law" according to the basic principles of the criminal proceedings, which can overcome the limitation arising from the formulation of the law to pursue the value of stability, and put an end to the possibility that the judges refuses to judge on the grounds that the law is not explicitly stipulated. [7]To the procedural content, the basic principle of the criminal proceedings is to authorize the judges to arrange the litigation activities reasonably according to the specific situation of the case, so as to achieve and realize the procedural justice. In a word, like other legal principles, the basic principle of the criminal proceedings, can play a role in overcoming the contradiction between the finiteness of the law and the infinite nature of the social relationship, the contradiction between the relative stability of the law and the change of social life, the contradiction between the justice of the law and the unjustness of the specific provisions of the law in special circumstances. In particular, the basic principles of the criminal proceedings have the functions empowering the judges with active justice mainly in the following aspects.

Firstly, the basic principles of the criminal proceedings are the basis for interpreting the criminal procedure regulations. Because of the abstractness of the legal rules, the judges always need to explain the precise meaning of the legal rules when applying them to specific cases so as to accurately define its constituent elements and legal effect, make it concrete and clear and become applicable. All natural languages are ambiguous and uncertain and individual cases are unique. So in order to form special rules related to the cases at hand, it is inevitable to interpret the statutory law or study the legal precedent in detail. [8] When interpreting the criminal procedure regulations, the judges must base themselves on the basic principles of the criminal proceedings. If there are two opposite meanings, they should adopt the meaning consistent with the basic principles of the criminal proceedings. There are many methods of legal interpretation, but no matter what method is adopted, the result of its interpretation cannot violate the principles of law and the interpretation of violating the principles of law shall not be called correct interpretation. All laws do the same and the criminal procedure law is no exception. The procedural rules of the criminal procedure law are abstract in nature, and judges must interpret them when applying the rules of the criminal procedure to deal with specific cases. When interpreting the rules of the criminal procedure, the judges must follow the basic principles of the criminal proceedings. Only by interpreting the applicable legal provisions according to the basic principles of the criminal proceedings can a judge apply them to specific cases.

Secondly, the basic principles of the criminal proceedings can supplement the loopholes of the criminal procedure law. Because of the inherent limitations, the statutory law cannot provide for all problems. Sometimes the judges are unable to obtain a basis for adjudication from existing law when trying cases, which indicates that there are loopholes in the existing law. [9] The existence of loopholes in the law creates a blind spot for the judges but they cannot refuse to judge because of loopholes in the law. So the judges can only seek to supplement legal loopholes through judicial activism and the basic principles of the criminal proceedings are one of the means for the judges to supplement the legal loopholes. In other words, in the absence of corresponding specific provisions in the current law, the judges can directly apply the basic principles of the criminal proceedings to judge cases.

\section{CONCLUSION}

The criminal procedure law itself is a normative system of concepts, rules and principles and the basic principle of criminal proceedings is in the fundamental normative position in this normative system, which constitutes the principle, basis and source of other procedural rules in the criminal procedure law. This feature makes it play the functions as the legislative rule, the code of conduct and empowering the judges with active justice. The function of the basic principle of the criminal proceedings is of great significance in the practice of the criminal procedure, which can solve many problems in the practice of criminal procedure, such as using it to regulate and guide the separation of the right of criminal trial and right of criminal execution and the separation of detention and investigation and so on. In this paper, the function of the basic principles of the criminal proceedings in practice is not discussed in detail, which is one of the problems that need to be further studied in the future.

\section{REFERENCES}

[1] Yong-ming Wang, On Theoretical Basis of System of Basic Principles of Criminal Procedure, Journal of Politics and Law 41(1) (1999)40-51.

[2] Rui Yan, Course of Criminal Procedure Law, China University of Political Science and Law Press, 1986, pp. 57.

[3] Rui-hua Chen, Research of Principles of Criminal Justice, Peking University Press, 1997, pp.128-131.

[4] You-ping Xie, Yi Wan, Principles of Criminal Procedure Law: Cornerstone of Procedural Justice, Law Publishing House Press, 2002, pp. 61-62. 
[5] Chong-yi Fan, Course of Criminal Procedure Law, China University of Political Science and Law Press, 1995, pp. 98-99.

[6] Rocos:Pound, Social Control through Law: Task of Law, Commercial Press, 1984, pp. 135.

[7] Shao-lin Chen, Wei Gu, On Right of Criminal Action, China Legal Publishing House Press, 2008, pp. 231-234.

[8] Rui-hua Chen, The front of criminal procedure law, Law Publishing House Press, 2005, pp.233-234.

[9] Rong-bin Chen, Course of Foreign Criminal Procedure Law, Law Publishing House Press, 2000, pp.211-212. 